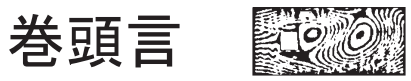

\section{学際的研究+アルファ \\ Interdisciplinary Study and Plus More}

鈴木 修*1

Osamu SUZUKI

1.はじめに

昨年に世界的に猛威をふるいはじめた新型コロナウィ ルスは, 社会に大きな影響を与えている。当学会において も, 年次総会や理事会, 各委員会がリモートで行われるよ うになったことをはじめ, 研究の進め方, 人によっては研 究テーマにも影響を与えている。ウィルスの飛沫の飛散 に関する流体力学的なシミュレーションが, 我が国が誇 るスーパーコンピュータである「富岳」により行われ，そ の結果が、ニュースで取り上げられたことも従来なら考 えられなかったことだろう。まずは, 年頭において, 新型 コロナ禍が克服され，一刻も早く安心で安全な日常が取 り戻されることを祈りたい。

さて, タイトルの学際的十アルファにもどることとす る。

2. 学際的十アルファについて

日本風工学会の大きな特徴のひとつは, 学際的な学会 であることである。ご存知の通り会員には理学系, 工学 系, 農学系, 社会学系などの様々な専門を持った多様なメ ンバーが参加し, 活動している。

私的な経験ではあるが, 当学会が学際的であることは, 自らの研究や関連する業務において, 大きな助けとなっ た。

当学会に入る前から, 竜巻やダウンバーストといった 突風現象の研究を気象学に関する研究を行っていた。そ
の一環として竜巻等突風の被害調査などを行っており, その過程で, 風災害研究会の活動を知り, 2005 年に当学 会に入会することになった。入会直後の 2005 年 12 月に は突風による羽越線脱線事故が，また，2006 年には 9 月 の延岡竜巻と 11 月の佐呂間竜巻と, 顕著な被害が連続し て発生した。所属していた気象研究所は気象庁に属して いたこともあり, 当時, 佐呂間竜巻については現地調査結 果等を分析やとりまとめを行い，竜巻の強さに関する知 見や被害の状況などについて, 当学会の関係者には様々 な有益な助言をいただいたことを記憶している。また, こ の後に科学技術振興調整費により学際的に行われた研究 は，その後のドップラーレーダー等を使った気象庁の竜 巻等突風に関する情報の提供にも影響している。

その後, 2012 年に発生したつくば竜巻や翌 2013 年の越 谷竜巻の調査や対策の検討を契機に，より正確で迅速な 被害の把握のため, 日本版の $\mathrm{EF}$ スケールの策定が課題と なり, この課題に答えるべく 2016 年 12 月には日本版フ ジタスケールの策定と翌年 4 月から気象庁の現地調査で の利用が始まった。この日本版フジタスケールの策定で は, 気象庁のもとに, 気象学会や風工学会をはじめとする 有識者の参加する会議が組織され, 風工学会メンバーの 研究成果が活用されている。

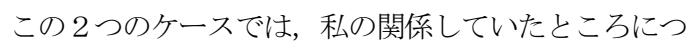
いてではあるものの，災害の発生 $\rightarrow$ 学際的な研究 $\rightarrow$ 社会 実装のための研究 $\rightarrow$ 実際の利用, といった流れが比較的 スムーズに繋がっていた。また, 社会実装の結果として,

* 1 気象研究所台風・災害気象研究部第 2 研究室 研究官 osuzuki@mri-jma.go.jp Researcher, Department of Typhoon and Severe Weather Research Second Laboratory, Meteorological Research Institute 
ドップラーレーダー網の展開の加速や, 突風被害の調查 の充実などが進み，竜巻等の風災害に関する研究にも反 映するといった, 正のフィードバックとなっている。同様 なケースは, 他の会員の研究にも見られたのではないか。

当学会の対象とはやや離れるものの, 最近, 私は内閣府 が実施している第 2 期の SIP に戦略コーディネーターと いう立場で関係している。SIP は戦略的イノベーションプ ログラム（Strategic Innovation Program）の略で, 内閣府総 合科学技術・イノベーション会議が司令塔機能を発揮し て, 府省の枠や旧来の分野を超えたマネジメントにより, 科学技術イノベーション実現のために創設した国家プロ ジェクトであり, 国民にとって真に必要な社会的課題や 日本経済に寄与できるような世界を先導する課題に取り 組むものである。大きな特徵として, 基礎研究から社会実 装までを見据えた取組であることが言える。現在の第 2 期では，12 の分野が設定され，それぞれの分野毎に概ね 5 年間の研究実施計画が立て, 進められている(なお, SIP に興味がある方は，内閣府の関連ページを見ていただき たい)。このうち，「国家レジリエンス（防災・減災）の強 化」のテーマでは, 現在, 様々な自然災害に対して, 研究 計画を立てられている。災害は, 学問的な分野といった人 為的な枠組みには収まらない。また, 防災のためには, 災 害情報の素早い収集と情報共有, 効果的な情報提供とそ の利用の実現も大切である。最初から, 学際的な研究 $\rightarrow$ 社 会実装のための研究まで意図している。そのため, 関連す る様々な分野の知恵が総合される必要があり, 学際的な 研究をべースとして, 研究の出口である社会実装までつ ながる興味深い成果も出ている。それぞれの研究計画は, 多岐に渡っており, 個々の研究グループの連携では, 今回 の計画に参加したことが契機となったものも多いが, 従 来からの学際的な研究グループ同士のつながりが発展し たものも多い。

\section{3.さいごに}

近年は, イノベーション指向も顕著であり, 学際的な研 究に加えて, 社会的価值やその創造につながるような学 際的十アルファな研究が求められていることも増えてき ている。「技術革新」と訳されることも多いイノベーショ ンという語は, 単に技術的な意味を指すだけではなく,た とえば,「科学的発見や技術的発明を洞察力と融合し発展 させ、新たな社会的価值や経済的価値を生み出す革新 (第 3 期科学技術基本計画)」のように, 社会への波及効果が あることを含んでいる。
す心゙ての学際的な研究に, 社会的に分かりやすい出口 がある必要はないものの, 両者がうまく噛夕合うことで 相乗効果が生まれることは, 今後ますます重要になって くると思われる。そのためには, 普段から, 学術的な発表, 学術研究会や各種委員会への参加などが大いに役立つも のと信じている。 